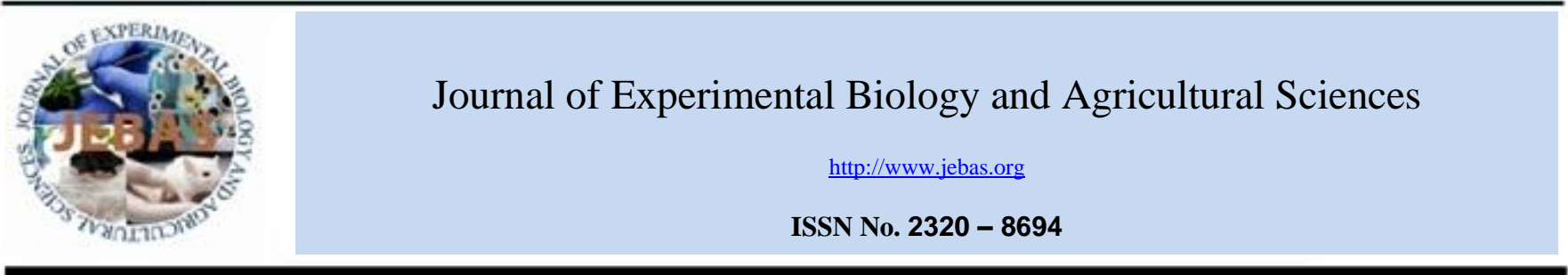

\title{
NATURAL HOME REMEDIES MAY ACT AS POTENTIAL IMMUNOMODULATORS TO PROTECT AGAINST SARS-COV-2 INFECTION
}

\author{
Department of Biochemistry and Nutrition BBD University, Lucknow-226028 \\ Received - September 25, 2020; Revision - October 24, 2020; Accepted - October 28, 2020 \\ Available Online October 30, 2020
}

Sandeep Negi, Lakshmi Bala*

DOI: http://dx.doi.org/10.18006/2020.8(Spl-1-SARS-CoV-2).S176.S189

\section{KEYWORDS \\ Home remedies \\ Herbs \\ Spices \\ Citrus fruits \\ Immunomodulatory effects \\ COVID-19}

\begin{abstract}
Corona virus disease 2019 (COVID-19) is primarily caused by Severe acute respiratory syndrome coronavirus 2 (SARS-COV-2). The infection begins with flu like symptoms with respiratory problems but in severe cases it affects cardiovascular system and excretory systems. On March 11, 2020 World Health organization (WHO) announced this disease as pandemic. Researchers are working continuously to find a proper treatment in the form of an effective vaccine or drugs/medicines but till date these are not available in the market and mainly symptomatic treatment is provided to COVID-19 patients. Under these circumstances, Ministry of Health and AYUSH, India has released advisory to people to use natural home remedies as potential alternative treatment. Home remedies are easily available at home in the form of spices and herbs e.g. citrus fruits, garlic, ginger, turmeric, ashwagandha, mulethi, tulsi, oregano, ginseng etc and have immunomodulatory effects as evidenced by ayurvedic literature and scientific publications. As per WHO guidelines the use of herbs within permissible limit would be helpful to manage COVID-19 but its overuse may have harmful effects. In the present article authors attempted to draw the attention of readers about the easy availability and affordability of home remedies to boost immunity and general well being of our body to fight against COVID-19.
\end{abstract}

* Corresponding author

E-mail: lakshmi266@gmail.com (Dr. Lakshmi Bala)

Peer review under responsibility of Journal of Experimental Biology and Agricultural Sciences.

Production and Hosting by Horizon Publisher India [HPI] (http://www.horizonpublisherindia.in/).

All rights reserved.
All the articles published by Journal of Experimental Biology and Agricultural Sciences are licensed under a Creative Commons Attribution-NonCommercial 4.0 International License Based on a work at www.jebas.org.

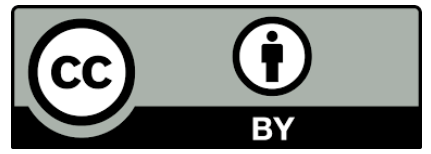




\section{Introduction}

Corona virus disease 2019 (COVID-19) is primarily caused by severe acute respiratory syndrome coronavirus 2 (SARS-CoV-2) and has presently caused a very severe pandemic affecting many countries across the globe and seeming to be challenging to control its spread (Dhama et al., 2020a; Rodriguez-Morales et al., 2020). It is believed that this disease originated from bats or pangolin and then got transmitted to humans (Zhou et al., 2020; Malik et al., 2020; Tiwari et al., 2020). For the first time it was noticed during December 2019 in China and gradually kept spreading to different countries. But the world came to know about its severity when WHO declared it as pandemic on March 11, 2020. Researchers worldwide are working hard to develop effective COVID-19 vaccines and drugs, few of these have entered in clinical trial stages (Rabaan et al., 2020; Yatoo et al., 2020). The disease begins with flu like symptoms and gradually becomes severe in some cases where immunity is not strong enough with symptoms like shortness of breath, respiratory problems and pneumonia leading to the multiple organ damage and finally death of the patient (Dhama et al., 2020b). There are two main factors that play a significant role in protecting our body from infectious viral diseases like COVID-19, dengue, swine flu and other deadly infectious diseases, viz. nutrition and immunity (Dhama et al., 2015; Dhama et al., 2018; Tiwari et al., 2018; Panyod et al., 2020). The immune system is considered as primary defense mechanism against any type of infection inside our body. It is very important for each and every individual to boost its immunity. It is wisely suggested by nutritional expert that balanced diet containing rich amount of nutrients with use of natural home remedies can help to strengthen our immune system (Mahima et al., 2013; Rahal et al., 2014; Bailly \& Vergoten 2020). These natural home remedies are rich source of vitamins, minerals, antioxidants and various other active ingredients that are very beneficial for boosting immunity (Dhama et al., 2018; Dhama et al., 2018; Tiwari et al., 2018). Herbs and medicinal plants like Tulsi, Marich, Sunthi, Dalchini, Ginger, Giloy and others are commonly used traditional medicines in home, and few of such traditional herbs have been suggested to be beneficial in countering SARS-CoV-2 infection and treating COVID-19 patients (Adithya et al., 2020). The Ministry of AYUSH, Government of India has recommended 'Ayush Kwath' for improving immunity and counter SARS-CoV-2 infection during COVID-19 pandemic owing to its immunomodulatory, antiviral and other modes of action (Gautam et al., 2020). In the present article authors attempted to draw the attention of readers about the use of easy available and affordable home remedies that can boost our immunity to fight against SARS-COV-2 infection. The article discusses the scientific basis of the ingredients present in each of the important natural home remedies playing a role in preventing SARS-CoV-2 infection. The Figure 1 depicts the different roles that natural remedies that may play crucial impacts to act as a shield against viral infection.

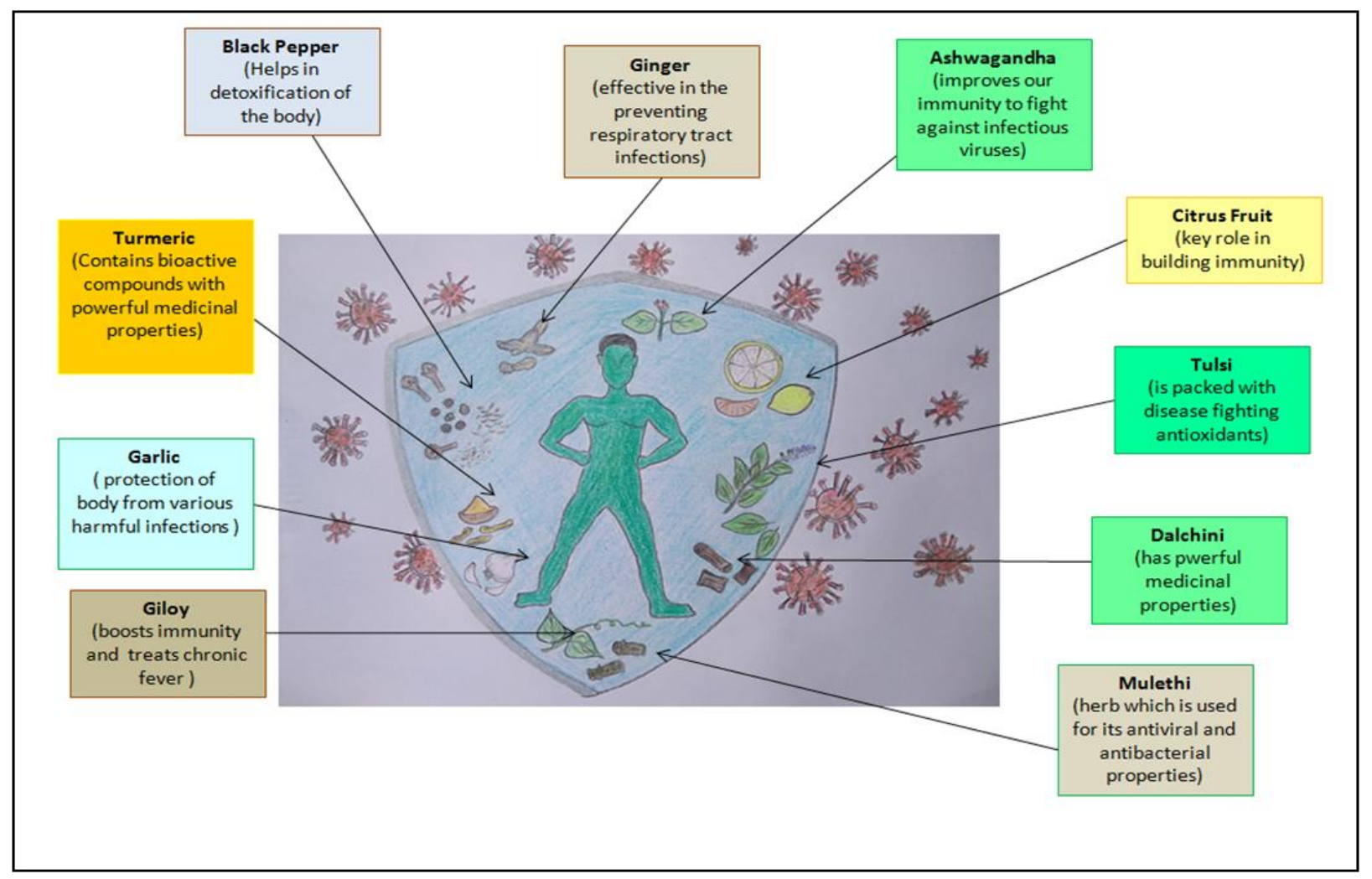

Figure 1 Natural home remedies may act as a shield against SARS-COV-2 infection

Journal of Experimental Biology and Agricultural Sciences http://www.jebas.org 
2 Important natural home remedies

\subsection{Citrus Fruits}

Citrus fruits include lemons, orange, clementines, tangerines, Grapefruit etc. They are rich sources of Vitamin C, flavanones and carotenoids etc. (Najmanová et al. 2019; Singh, 2020). Vitamin C is neither synthesized nor is stored inside our body. It is categorized as water soluble vitamin (Tiwari et al., 2018). The daily requirement of vitamin $\mathrm{C}$ in sufficient amount $(75 \mathrm{mg}$ for women and $90 \mathrm{mg}$ for men) is important for keeping body healthy. Citrus fruits play a key role in maintaining immunity to our body to fight against various viral infections. The spike $\mathrm{S}$ protein of SARS-COV-2 virus enters the host cell by binding to ACE2 receptor of host epithelial cell (chiefly lung, gastrointestinal tract etc). It has been reported that Hesperidin is one of the flavones present in citrus fruit, which may block binding of S protein to ACE2 receptor (Bellavite \& Donzelli, 2020). Apart from it, it promotes functioning of white blood cells, which plays key role in fighting infections (Maggini et al., 2007; Webb \& Villamor, 2007; Chen et al., 2020). Vitamin C has been reported to play protective role in COVID-19 patients (Hoang et al., 2020). Figure 2 summarizes the different role of Vitamin $C$ in immunomodulation (Carr \& Maggini, 2017).

\subsection{Oregano}

It is used as a medicinal herb which is also known as Lippia graveolens. It is mainly found in the region of Central America and Mexico. Oregano contains an essential oil named Carvacrol (Pilau et al., 2011) which has antiviral properties as shown in various studies e.g. against Respiratory Syncytial Virus (RSV) (Chidgey \& Broadley, 2005), Murine Norovirus (MNV) responsible for stomach flu (Gilling et al., 2014) and various other RNA and DNA viruses (Ball \& Knipe, 2007; Pilau et al., 2011). So, it could be a very good option as a natural home remedy during this COVID-19 pandemic.

\subsection{Ginseng}

Ginseng is widely known for its antimicrobial properties. Various research articles showed its activity against pathogenic viruses. Additionally, it has a preventive role in the treatment of cancer, heart related diseases and also improves immune system (Kim et al., 2000). It is documented in various studies to have antiviral action against a number of viruses causing respiratory disorders (Lee et al., 2014a; Lee et al., 2015). For example against RSV, which shows similar symptoms like COVID-19 infecting the

\section{Role of Vitamin C in immunomodulation}

\begin{tabular}{|c|c|c|}
\hline & & \\
\hline - Antioxidant property & & - Increase collagen \\
\hline -Increases chemotaxis & & -Antioxidant properties \\
\hline -Increases phagocytos & $\begin{array}{l}\text { Vitamin C Rich } \\
\text { Citrus Fruit }\end{array}$ & species(ROS) \\
\hline -Aid in apoptosis & & $\begin{array}{l}\text { - Helps keratinocytes to } \\
\text { differenciate and become } \\
\text { functional }\end{array}$ \\
\hline & $\downarrow$ & •Lipid formation \\
\hline $\begin{array}{l}\text { T-cell and B-cell Activity } \\
\text { - Increases formation and } \\
\text { development to functional } \\
\text { state } \\
\text { - Increases antibody } \\
\text { formation }\end{array}$ & $\begin{array}{l}\text { Inflammation mediation } \\
\text { - Facilitates cytokine } \\
\text { formation } \\
\text {-Reduces histamine } \\
\text { secretion }\end{array}$ & $\begin{array}{l}\text {-Fibriblast synthesis and } \\
\text { movement } \\
\text { - Reduces wound healing } \\
\text { time }\end{array}$ \\
\hline
\end{tabular}

Figure 2 Important roles of Vitamin C

Journal of Experimental Biology and Agricultural Sciences

http://www.jebas.org 
respiratory system and finally leading to pneumonia and bronchiolitis (Kim \& Park, 2011; Munoz, 2015), different types of Influenza virus (Claas et al., 1998; Neumann et al., 2009). It showed immunomodulatory effects in patients infected with viral infection like H1N1 and also neutralizes the reactive oxygen species (ROS) formed during infection ( Lee et al., 2014b).

\subsection{Garlic}

Garlic is also known as Allium Sativum L., is a popular traditional medicinal herb since ancient times and it is documented in ayurveda as antimicrobial and antiparasitic. The main odour of garlic is due to a number of sulphur compounds, the chief one is Allicin (diallylthiosulphinate) (Gruhlke et al., 2016). Allicin is reported to play a key role in formation of T-cell and B-cell (Salman et al., 1999); it stimulates CD8+ cells and T lymphocytes cells of immune system (Reinhart et al., 2009) against various viral infections like influenza A and B, HIV, HSV-1, viral pneumonia, and rhinovirus (Zhen et al., 2006; Sawai et al., 2008), and recently also suggested to be effective against SARS-CoV-2 infection (Donma \& Donma, 2020). Garlic has contains fructooligosaccharides which exhibits important role in immunomodulation. The extract of garlic is reported to be antiinflammatory, anti-atherosclerotic and regulates blood pressure (Arreola et al., 2015).

\subsection{Ginger}

Ginger, also known as Zingiber Officinale Roscoe. It is a famous spice which not only adds taste and flavour to food but also very rich in medicinal properties. Ginger tea or ginger extract is commonly used since ages to treat common cold or flu and sore throat (Chang et al., 2013). Its active constituent gingerol- is an antioxidant that boosts our immune system and has antiviral properties and helps in treatment of respiratory problems, and recently reported to be beneficial for COVID-19 patients (Aboubakr et al., 2016; Safa et al., 2020). It contains important enzymes like allinase, peroxidase, and myrosinase. Sulphur rich compounds like allicin, alliin, and ajoene are also among its important constituents. The presence of compounds like superoxide dismutase and glutathione peroxidase makes it a powerful antioxidant that plays a major role in the body defence mechanism against viral infections (Sharma, 2017). It is anti-inflammatory, analgesic, decreases blood cholesterol level and hence very useful in heart problems. A study showed hot water extract of ginger is very effective against respiratory syncytial virus (RSV), avian influenza, feline calicivirus (FCV) and norovirus. It prevents viral plaque formation in airways epithelium cells and blocks the viral attachment sites (Kim et al., 2006). The aqueous extract of ginger along with garlic and other herbs prevent food form being contaminated (Tripathi et al., 2020).

\subsection{Ashwagandha}

Ashwagandha also known as "Indian Ginseng", is Withania somnifera. It is easily found in the Indian subcontinent and has many medicinal properties (Tiwari et al., 2014). The word Ashwagandha gets its origin from Sanskrit which means "Smell of Horse". This Sanskrit meaning relates with the power and fast activity of a horse (Tripathi et al., 2020). Consumed in the powder form, it is famous for its therapeutic values in the treatment of arthritis, asthama, hypertension and inflammation (Singh et al., 2011). It is a powerful immunomodulator and enhancs activity of T- helper cell (Singh et al., 2008). Ashwagandha is used as an anti depressant and stress reliever to improve physical health. It is also used as an anti-ageing medicine (Tripathi et al., 2020). It is also helpful in regulating blood glucose and cholesterol level in our body. This herb has been recently studied for its anti-SARS-CoV-2 potential (Shree et al., 2020). Withania somnifera (Indian ginseng) has been reported to inhibit SARS-CoV2 host entry and replication as deduced from an in-silico study (Chikhale et al., 2020). Ashwagandha contains bioactive compounds such as withanone (Wi-N) and Withanoside $\mathrm{V}$ which have ability to stop the replication of SARS-COV-2 (Tripathi et al., 2020). The various benefits of ashwagandha have been depicted in Figure 3.

\subsection{Mulethi (Licorice)}

Mulethi is scientifically known as Glycyrrhiza glabra $\mathrm{t}$ is a medicinal herb. It consists of rich amount of triterpenoids and huge variety of flavonoids of which the important ones are shown in Figure 4. It is known for its antiviral, antibacterial, anti inflammatory and anti tumour properties, and recently suggested to have anti-SARS-CoV-2 potential (Ahn et al., 2012; Adianti et al., 2014; Wang et al., 2015; Dhama et al., 2018; Sinha et al., 2020). In China it is popularly called as 'sweet grass' and was first time included in 2100 B.C (Wang et al., 2015). The predominant antiviral ingredients and its mode of action is represented in Table 1 while the ingredients exhibited as antifungal and antibacterial agent are given in Table 2.

\subsection{Tulsi}

It is scientifically named as Ocimum sanctum Linn. It is a religious herb, which is worshiped in many parts of India. It contains many flavonoids and phenolic compounds, the important ones are apigenin, eugenol, linalool and ursolic acid. Tulsi extract is antiviral and very effective against herpes, heptitis B and enterovirus, Dengue and swine flu. The presence of linoleic acid makes it a powerful anti-oxidant and neutralizes free radicals produced by harmful toxicants causing cellular damage (Panda \& Suresh, 2009). It is antibacterial, anti-inflammatory, anti-diarrheal, antipyretic, cardioprotective, reno-protective, hepato-protective, antimalarial and with immunomodulatory properties. It is effective to 


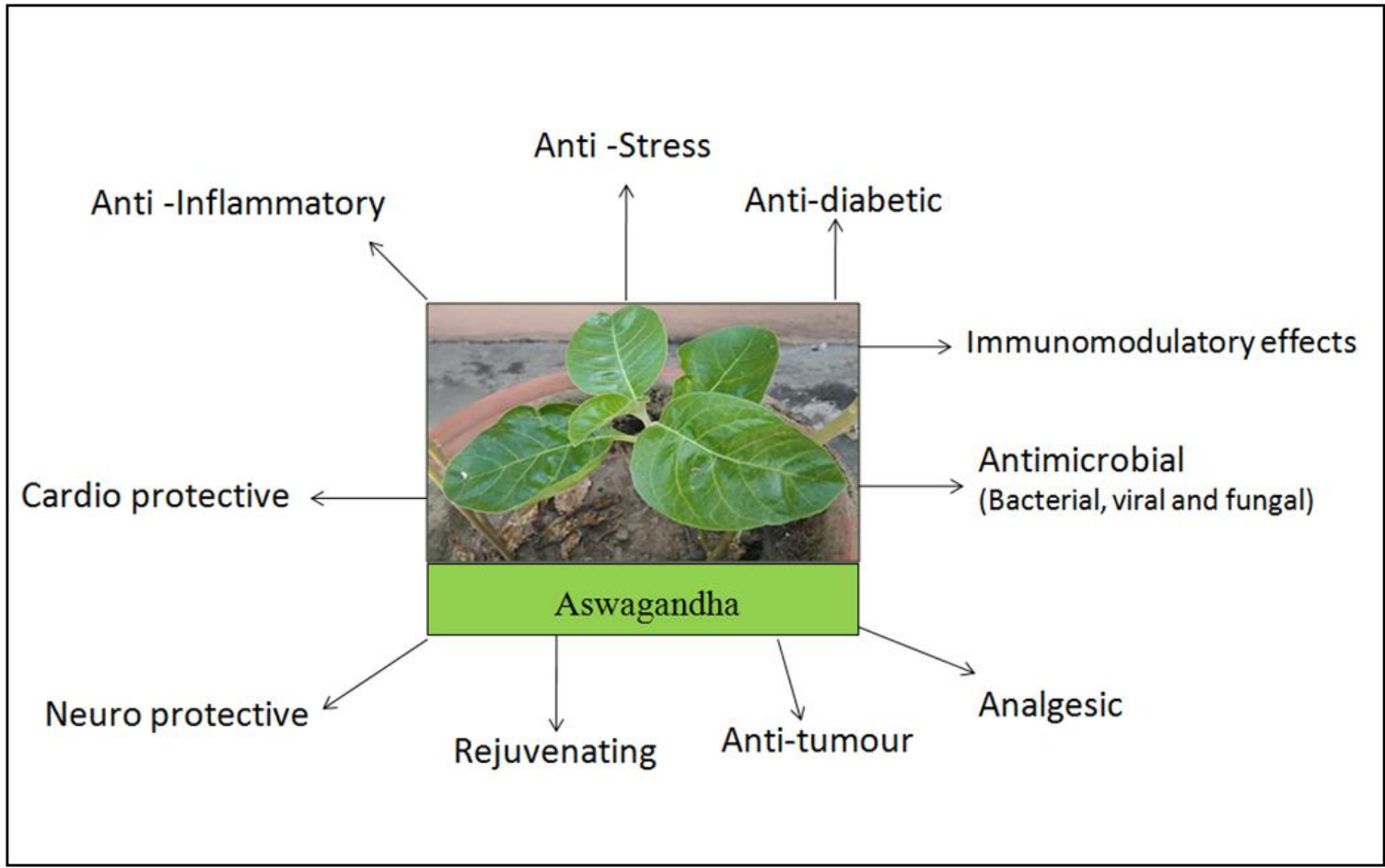

Figure 3 : Various benefits of Ashwagandha (Kapoor, 1990; Vyas et al., 2011; Ven et al., 2012; Tripathi et al., 2020)

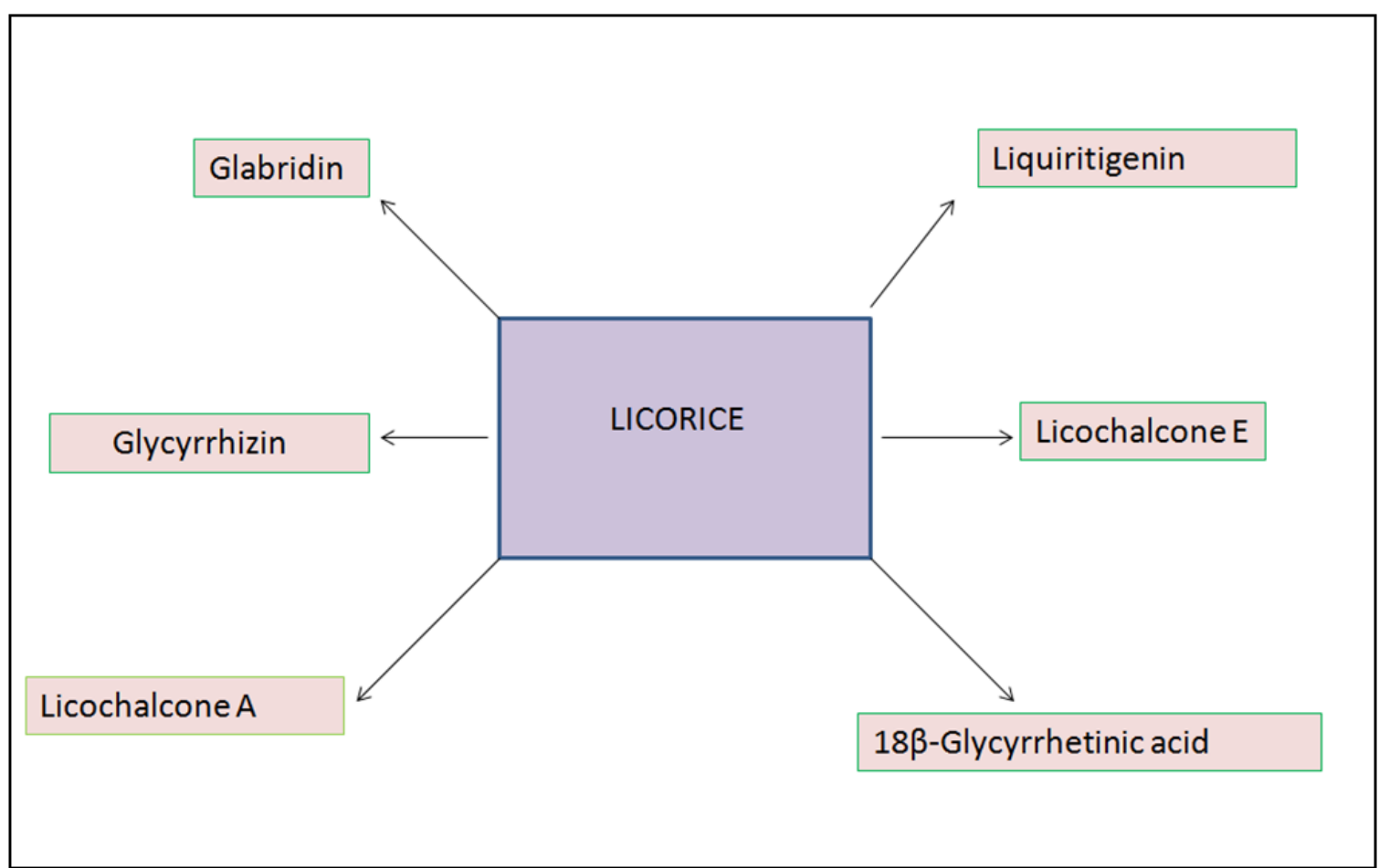

Figure 4 Beneficial ingredients of Mulethi (Licorice) (Wang et al., 2015)

Table 1 Antiviral ingredients in Mulethi and their working mechanism (Ahn et al., 2012; Adianti et al., 2014)

Journal of Experimental Biology and Agricultural Sciences http://www.jebas.org 
Table 1 Antiviral ingredients in Mulethi and their working mechanism (Ahn et al., 2012; Adianti et al., 2014)

\begin{tabular}{|c|c|c|}
\hline Name of Virus & Active Ingredient & working mechanism \\
\hline Hepatitis C & \multirow{8}{*}{ Glycyrrhizin } & $\begin{array}{l}\text { It stop release of virus when transmitted from one cell to another } \\
\text { Prevents expression of viral genetic material }\end{array}$ \\
\hline Herpes Simples & & $\begin{array}{l}\text { Reduces adhesion between cerebral capillary vessel endothelial cells and } \\
\text { neutrophils }\end{array}$ \\
\hline Cocksackie virus B3 & & Protects from Failure of nuclear factor inhibitor \\
\hline Duck hepatitis virus & & Helps in the formation of T-Cell \\
\hline H5N1 & & $\begin{array}{l}\text { Decreases production of C-X-C-L- } 5 \text { by virus } \\
\text { Decreases cell death due to virus }\end{array}$ \\
\hline Influenza & & $\begin{array}{l}\text { Reduces the linking between HMGB1 and DNA } \\
\text { Hampers functioning of viral polymerase enzyme }\end{array}$ \\
\hline Cocksackie virus A16 & & Deactivates the virus \\
\hline Herpes simplex 1 & & Stops virus multiplication \\
\hline Rota virus & \multirow{2}{*}{ Glycyrrhetinic acid } & Reduces viral protein level \\
\hline Human orthopnuemovirus & & $\begin{array}{l}\text { Prevents viral attachment to cell } \\
\text { Promotes production of interferon }\end{array}$ \\
\hline
\end{tabular}

Table 2 Antibacterial and antifungal ingredients in Mulethi and their mode of action (Wang et al., 2015)

\begin{tabular}{|ccc|}
\hline Microbes & Ingredients in Mulethi & Mode of action \\
\hline Staphylococcus aureus & 18ß-Glycyrrhetinic acid & Inhibits expression of viral genes (SaeRandHla) \\
\cline { 3 - 3 } Candida albicans & & Aids T-helper cells \\
\hline Candida albicans & Licochalcone A & $\begin{array}{c}\text { Prevents biofilm formation } \\
\text { stops transition of hyphae }\end{array}$ \\
\hline Staphylococcus aureus & Licochalcone $\mathrm{E}$ & Decrease $\alpha$ toxin synthesis \\
\hline Candida albicans & Glabridin & Stops transition of hyphae \\
\hline Staphylococcus aureus & Liquiritigenin & Decrease $\alpha$ toxin synthesis \\
\hline
\end{tabular}

fight against cold, fever, diarrhoea, anxiety, cardiac and genitourinary problems (Pattanayak et al., 2010; Mohan et al., 2011; Mondal et al., 2011; Cohen, 2014). The anti-inflammatory and antioxidant properties of tulsi plant make it best natural home remedy for treatment of covid-19 infection (Suanarunsawat et al.,2011). It also works as an immunomodulator as it increases the formation of $\mathrm{T}$ helper cell and $\mathrm{NK}$ cells in the body (Lo et al., 2002; Mondal et al., 2011; Hemalatha et al., 2011). Recently, $O$. sanctum has been found to provide protection from SARS-CoV-2 infection (Dharmendra \& Deepak, 2020; Shree et al., 2020). Figure 5 summarises various beneficial health effects of Tulsi.

\subsection{Dalchini (Cinnamon)}

It is a medicinal herb which is scientifically known as Cinnamomum zeylanicum Breyn. It is used as a natural immunity booster in flu, edema, cough and indigestion (Niphade et al., 2009). Its main chemical constituents are Cinnamaldehyde, Cuminaldehyde and Eugenol. Its bark consists of various beneficial compounds like benzaldehyde, cinnamaldehyde, cuminaldehyde and terpenes
(Valizadeh et al., 2015). It stimulates immunity i.e. cell mediated and humoral immunity, by increasing levels of immunoglobulins and phagocytic index (Niphade et al., 2009). It is reported as a regulator of cell mediated immunity due to its property of obstruction of NF$\mathrm{kB}$ which triggers signaling components, PDK1 and NF-kB (Gautam et al., 2020). Dalchini also activate CD29 and CD43 leading to blocking of cell migration and induced attachment of one cell other cell. It reduces the production of nitric oxide and also upregulate level of CD80 and CD69 and specific receptors like TLR2 and CR3that help in pattern recognition. Extract made by barks of dalchini decreases the amount of IFN- $\Upsilon$ without impacting the IL4 level or the IL-2 level. It also inhibits IFN- $\Upsilon$ and IL-4 induced anti-CD3 antibody at the m RNA and secreted protein levels increase IL2 protein secretion at the cellular level, helping to minimize cell death. It inhibits the expression of IL-2 mRNA, inhibits p38, JNK, ERK1/2 and STAT4 mediated anti-CD3 activation, but does not degrade 1k B or STAT6 (Gautam et al., 2020). This demonstrates dalchini's immunomodulatory effect on cytokine secretion and its role in activated $\mathrm{T}$ cell signalling molecules. It also contributes to a reduction in the subG1 process and 


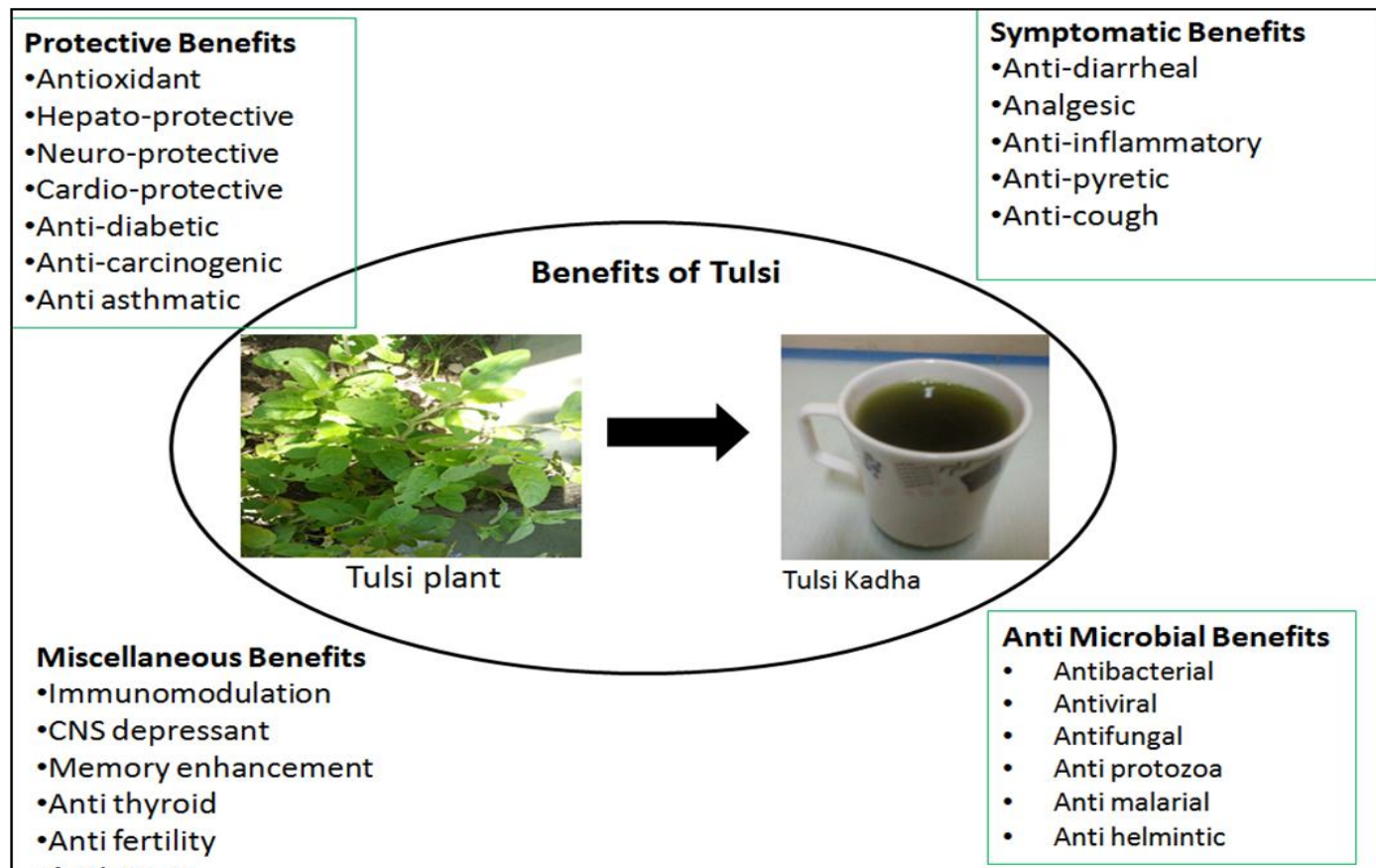

-Anti stress

Figure 5 Benefits of Tulsi (Pattanayak et al., 2010; Mondal, 2010; Mondal et al., 2011; Mohan et al., 2011)

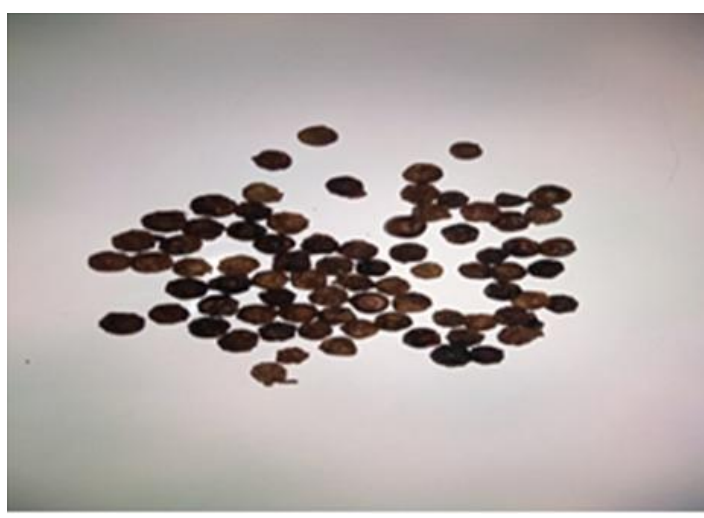

Kali mirach

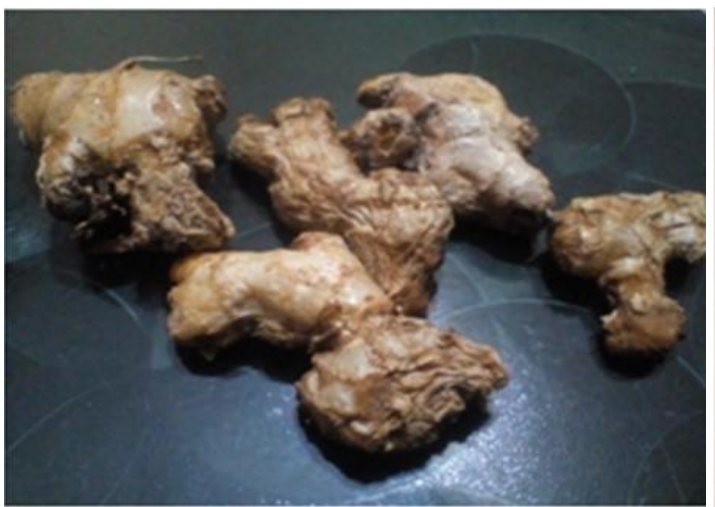

Ginger

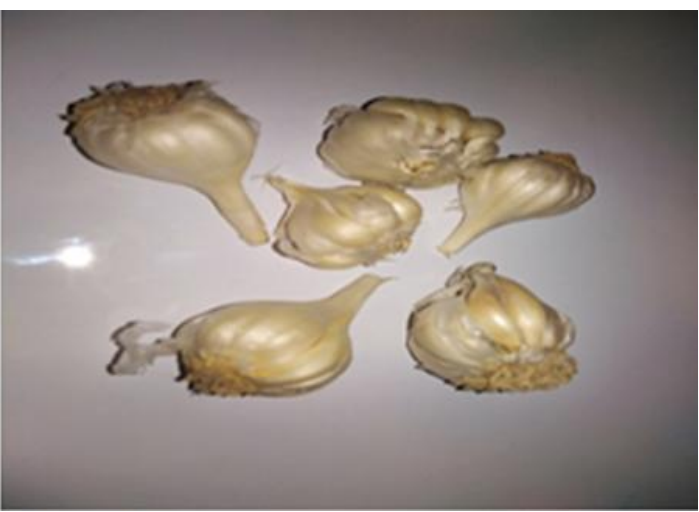

Garlic

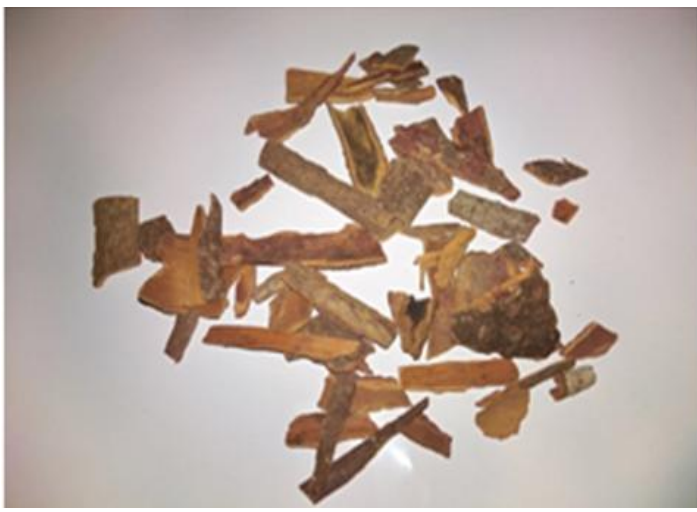

Dalchini

Figure 6 Spices as natural home remedies: Garlic, Ginger, Dalchini and Kali Mirch,

Journal of Experimental Biology and Agricultural Sciences http://www.jebas.org 

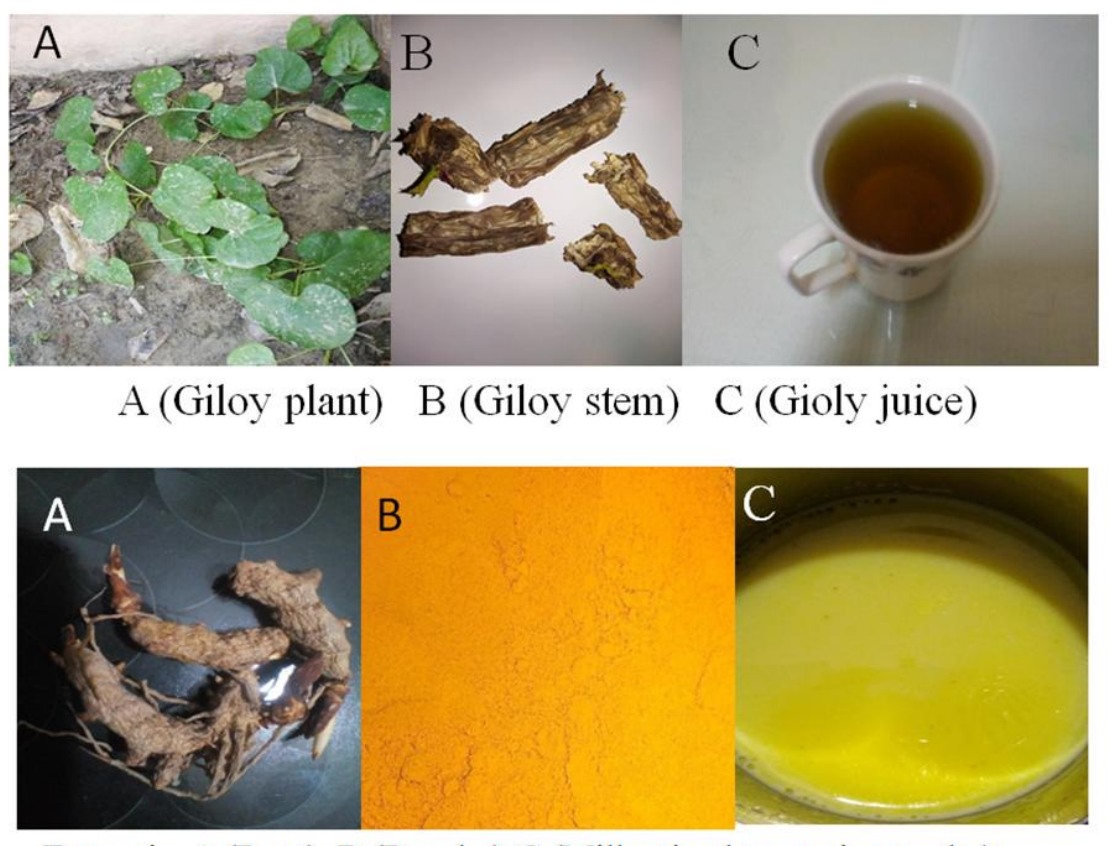

Turmeric A (Root) B (Powder) C (Milk mixed turmeric powder)

Figure 7 Giloy and Turmeric with immunomodulatory effect

raises the ratio of necrotic to apoptotic cells. The constituents (cinnamaldehyde and cinnamophilin) are the receptor antagonist thromboxane A2. It is anticoagulative and anti-atherosclerotic, thus avoiding unwanted platelet clumping (Tsui et al., 2018). Recently, SARS-CoV-2 inhibitors have been identified from Cinnamon via in silico studies (Prasanth et al., 2020).

\subsection{Kali Mirch}

Kali Mirch is scientifically known as Piper nigrum. It has antioxidant, anti-inflammatory , anti-parasitic, anti-asthmatic, anti-depressant, anticarcinogenic , anti-diarrheal, anti-ulcer, anti-thyroid, anti-mutagenic, anti-apoptotic, anti-bacterial , anti-viral and immunomodulatory properties. It also increases the therapeutic efficacy of various drugs, vaccine and nutrients (Nahak \& Sahu, 2011; Damanhouri, 2014; Srivastava \& Singh, 2017; Peterson et al., 2019). Its main ingredient is piperine, which is responsible for regulation of cytokines production of various types of immune cells like Th1, Th2, Th17 and Treg cells. It is responsible for decrease the aggregation of inflammatory cells as well, it avoids the expression of GATA3, IL-4, IL-6, IL-1 $\beta$, ROR, IL-17 A and TNF and increases the secretion of INF- and IL-10 in Bronchoalveolar lavage fluid. It also increases production of $\mathrm{T}$ cell and $\mathrm{B}$ cell and activate macrophage cells (Damanhouri, 2014; Balkrishna et al., 2020; Gautam et al., 2020). Piperine is cytotoxic in nature. It reduces the amount of immunoglobulin Ig E, anti-OVA IgE, anti-OVA IgE1 and release of histamine in serum. It increases fibrosis and inflammatory cell infiltration. It also hampers Th2/Th17 response and activates mast cell. It inhibits NF-kB, c-Fos, cAMP response binding feature, Factor-2 transcription activation. It decreases the expression of PMA mediated MMP-9, inhibits PKCa / extracellular signal-regulated kinase (ERK) $1 / 2$ and reduces the activation of NF-kB / AP-1. It is also responsible for p-glycoprotein inhibition and the role of CYP3A4 (Zhai et al., 2016; Bui et al., 2019).

\subsection{Giloy (Tinospora cordifolia)}

Giloy is also known as Tinospora cordifolia. It is a curing climber plant in which stem is main part with many beneficial properties. It contains a significant number of alkaloids, polysaccharides, glycosides and steroids (Panchabhai et al., 2008). The immunomodulatory, antidiabetic, antioxidant, antihepatotoxic and cytotoxic effects are popularly recognised (Sharma et al., 2012; Dhama et al., 2016). The active phytoconstituents responsible for its immunomodulatory activity are Tinocordioside, Cordifolioside A, Magnoflorine, and Syringin (Goyal et al., 2011). It is rich in antioxidants which neutralizes the free radicals and prevents inflammation. It effectively fights against harmful bacteria, fungus and viruses. It also flushes out toxins inside the body. The use of giloy kadha (juice) is very effective against harmful viruses. Anti-inflammatory properties help in the treatment of various types of respiratory problems like cold, cough and breathing problems. Its beneficial health properties have been suggested to inhibit SARS-CoV-2 and give relief to COVID-19 patients (Chowdhury, 2020; Dharmendra \& Deepak, 2020; Krupanidhi et al., 2020; Shree et al., 2020). Figure 7 shows stems of Giloy and turmeric. 


\subsection{Turmeric (Curcuma longa)}

It is commonly called as "Haldi" in India. Its active ingredient is polyphenolic compound known as Curcumin, which is antiinflammatory, anti-microbial and has immunomodulatory effect in our body (Gupta et al., 2020; Zahedipour et al., 2020). It inhibits virus entry into the cell, inhibits virus and virus protease encapsulation, and modulates multiple cellular signaling pathways (Zahedipour et al., 2020). In the treatment of osteoarthritis and rheumatoid arthritis, it is also useful. Turmeric has been suggested to be a valuable option for treatment against COVID-19 (Babaei et al., 2020; Emirik, 2020). The main effects of curcumin on respiratory disorders are as follows.

\subsubsection{Effect of Curcumin on Pulmonary Inflammation}

Curcumin has its main role in the inhibition of inflammatory cytokines. Its presence blocks the critical signals controlling the expression of different pathways of pro-inflammatory cytokines such as nuclear factor B and MAPK (Ferreira et al., 2015). It has properties that are anti-inflammatory and anti-fibrotic. It reduces the expression of chemokines and cytokines, such as INF $\gamma$, MCP 1, IL-6, IL-10, involved in lung infection (Avasarala et al., 2013). By preventing viral replication, release of TNF alpha and down controlling phosphor-NF-alpha-B (Zahedipour et al., 2020), it demonstrates inhibitory effects against RSV infection.

\subsubsection{Effect of Curcumin on Pulmonary Fibrosis}

Pathways of curcumin inhibit apoptosis mediated by the p38MAP $\mathrm{K}$ route (Avasarala et al., 201).

\subsubsection{Effect on Pulmonary Oedema}

Pulmonary oedema is the condition when accumulation of fluid takes place in lungs. A recent study in SARS-COV-2 infection has shown that its envelope protein activates protein kinase $\mathrm{C}$, thus reducing the activity of epithelial sodium channels of pulmonary epithelial cells resulting into pulmonary oedema (DeDiego et al., 2014). Recent research study (Tian et al., 2020) has demonstrated the use of Curcumin decreases the inflammation that results in the reduction in the influx of fluid in lungs in experimental animals (rat).

\subsubsection{Effect of Curcumin in COVID-19 related heart problems}

Respiratory problems are caused by the binding of the SARSCOV-2 virus spike protein to the ACE2 respiratory epithelium cell receptor. These complications are more pronounced in person with cardiac problems. The explanation may be that AEC2 is more commonly expressed in cardio patients (Zheng, 2020). By minimising $\mathrm{c}$ Jun $\mathrm{N}$ terminal Kinase and NF- $к B$ nuclear translocation phosphorylation, curcumin prevents myocardial ischemia-reperfusion injury. It also reduces immune cell infiltration and the expression in vascular cells of binding molecules and pro-inflammatory mediators (Li et al., 2017).
2.12.5 Curcumin 's effect on kidney problems associated with COVID-19

The occurrence of acute injury to the kidneys was seen in COVID19. The high incidence in patients with diabetes may be due to the high expression of ACE2 in the kidneys (Ye et al., 2006) and may be the reason for renal damage. Curcumin up regulates AEC2 and ACE2 mRNA that contributes to the increase in flow of blood in kidneys in rat models (Xu et al. , 2018). By reducing inflammation caused by MCP-1, NF- кB, TNF, IL-1 $\beta$, COX-2 and COV-1, curcumin also decreases renal fibrosis at the stage of priming and activation. It decreases anti-inflammatory factors as well. In animal models, it targets MAPK / ERK, TGF- $\beta$ / smads and PPARpathways (Sun et al., 2017).

\section{Conclusion}

Modern life style, laziness and undisciplined eating habits results in the increase of various types of disorders like diabetes, respiratory problems, heart related diseases, kidney dysfunctioning etc. These kinds of problems create serious problems to an individual during this COVID-19 pandemic. Natural home remedies are easily available at home, cheap and affordable and may prove to be very beneficial as alternative treatment in this pandemic time, when there is shortage in medical facilities, unavailability of any vaccine and specific medicines. These herbs, spices and citrus fruits are potent immunomodulator and can boost our body immunity to fight against harmful virus like SARS-CoV-2. The names described in the present article are just a tip of iceberg. There are many more medicinal plants, fruits, vegetables and spices whose inclusion in the present article is beyond the scope. It has been reported that some of the phytoconstituents viz. Withaferin A, Withanolide B , Tinocordioside, Somniferine A, Tinosporide, Withanolide, Orientin, Flavonol glucoside, Apigenin, Kempferol, withanone from medicinal plants like (Tulsi, giloy and Ashwagandha) show interaction with SARS-CoV-2 and other target proteins. Tulsi herb contains dihydrodieuginol B and Tulsinol A, B, C, D, E, F, G which can work as potential inhibitor for papain like protease and SARS corona virus main protease. Healthy body with good immunity has an ability to fight against attack of infections like COVID-19. More researches on the important herbs, spices and medicinal plants would pave way for providing a useful remedy to fight against COVID-19.

\section{Conflict of interest}

The authors declare that there is no conflict of interests.

\section{Funding source}

There is no funding for this work. 


\section{References}

Aboubakr HA, Nauertz A, Luong NT, et al. ( 2016) In Vitro Antiviral Activity of Clove and Ginger Aqueous Extracts against Feline Calicivirus, a Surrogate for Human Norovirus. Journal of Food Protection 79(6):1001-1012. doi:10.4315/0362-028X.JFP-15-593.

Adianti M, Aoki C, Komoto M, Deng L, Shoji I, Wahyuni TS, et al. (2014) Anti-hepatitis C virus compounds obtained from Glycyrrhizauralensis and other Glycyrrhiza species. Microbiology and Immunology 58(3):180-87.

Adithya J, Nair B, Aishwarya S, Nath LR (2020) The Plausible role of Indian Traditional Medicine in combating Corona Virus (SARS-CoV 2): a mini-review. Current Pharmaceutical Biotechnology doi: 10.2174/1389201021666200807111359.

Ahn SJ, Cho EJ, Kim HJ, Park SN, Lim YK, Kook JK (2012) The antimicrobial effects of deglycyrrhizinated licorice root extract on Streptococcus mutans UA159 in both planktonic and biofilm cultures. Anaerobe 18(6):590-96.

Arreola R, Quintero-Fabián S, López-Roa RI, Flores-Gutiérrez EO, Reyes-Grajeda JP, Carrera-Quintanar L, Ortuño-Sahagún D (2015) "Immunomodulation and anti-inflammatory effects of garlic compounds." Journal of immunology research 3(4): 401630. doi:10.1155/2015/401630.

Avasarala S, Zhang F, Liu G, Wang R, London S D, London L (2013) Curcumin Modulates the Inflammatory Response and Inhibits Subsequent Fibrosis in a Mouse Model of Viral-induced Acute Respiratory Distress Syndrome. PLoS ONE. https://doi.org/10.1371/journal.pone.0057285.

Babaei F, Nassiri-Asl M, Hosseinzadeh H (2020) Curcumin (a constituent of turmeric): New treatment option against COVID-19. Food Science and Nutrition 8(10):5215-5227. doi: 10.1002/fsn3.1858.

Balkrishna A, Solleti SK, Singh H, Tomer M, Sharma N, Varshney A (2020) Calcioherbal formulation, Divya-Swasari-Ras, alleviates chronic inflammation and suppresses airway remodelling in mouse model of allergic asthma by modulating pro-inflammatory cytokine response. Biomedicine and Pharmacotherapy https://doi.org/10.1016/j.biopha.2020.110063.

Bailly C, Vergoten G (2020) Glycyrrhizin: An alternative drug for the treatment of COVID-19 infection and the associated respiratory syndrome.Pharmacology \& Therapeutics 214:107618. doi:10.1016/j.pharmthera.2020.107618.

Ball LA, Knipe DM (2007) Virus replication strategies. In: Knipe DM, Howley PM, Griffin DE, et al. (Eds) Fields virology, 5th ed. Lippincott Williams \& Wilkins, Philadelphia, PA.
Bellavite P, Donzelli A (2020) Hesperidin and SARS-CoV-2: New Light on the Healthy Function of Citrus Fruits. Antioxidants 9(8): 742 .

Bui TT, Piao CH, Hyeon E, Fan Y, Van Nguyen T, Jung SY, et al. (2019) The protective role of Piper nigrum fruit extract in an ovalbumin-induced allergic rhinitis by targeting of NFkBp65 and STAT3 signalings. Biomedicine \& Pharmacotherapy 109: 19151923. https://doi.org/10.1016/J.BIOPHA.2018.11.073.

Carr AC, Maggini S (2017) Vitamin C and immune function. Nutrients 9(11):1211.

Chang JS, Wang KC, Yeh CF, Shieh DE, Chiang LC (2013) Fresh ginger (Zingiber officinale) has anti-viral activity against human respiratory syncytial virus in human respiratory tract cell lines. Journal of Ethnopharmacology 145(1):146-151. doi:10.1016/j.jep.2012.10.043.

Chen L, Hu C, Hood M, Zhang X, Zhang L, Kan J, Du J (2020) A Novel Combination of Vitamin C, Curcumin and Glycyrrhizic Acid Potentially Regulates Immune and Inflammatory Response Associated with Coronavirus Infections: A Perspective from System Biology Analysis. Nutrients 12(4):1193. doi: 10.3390/nu12041193.

Chidgey SM, Broadley KJ (2005) Respiratory syncytial virus infections: characteristics \& treatment. Journal of Pharmacy and Pharmacology 57(11): 1371-1381.

Chikhale RV, Gurav SS, Patil RB, Sinha SK, Prasad SK, Shakya A, Shrivastava SK, Gurav NS, Prasad RS (2020) Sars-cov-2 host entry and replication inhibitors from Indian ginseng: an insilico approach. Journal of Biomolecular Structure and Dynamics 1-12. doi: 10.1080/07391102.2020.1778539.

Chowdhury P (2020) In silico investigation of phytoconstituents from Indian medicinal herb 'Tinospora cordifolia (giloy)' against SARS-CoV-2 (COVID-19) by molecular dynamics approach. Journal of Biomolecular Structure and Dynamics 1-18. doi: 10.1080/07391102.2020.1803968.

Claas EC, Osterhaus AD, van BR, De JJC, Rimmelzwaan GF, Senne DA, Krauss S, Shortridge KF, Webster RG (1998) Human influenza A H5N1 virus related to a highly pathogenic avian influenza virus. Lancet 351:472-477.

Cohen MM ( 2014) Tulsi-Ocimum sanctum: A herb for all reasons. Journal of Ayurveda and Integrative Medicine 5(4):251. https://doi.org/10.4103/0975-9476.146554.

Damanhouri ZA (2014) A review on therapeutic potential of Piper nigrum L. (Black Pepper): the king of spices. Medicinal and Aromatic Plants 3:3. https://doi.org/ 10.4172/2167-0412.1000161. 
DeDiego ML, Nieto-Torres J L, Jimenez-Guardeño J M, ReglaNava JA, Castaño-Rodriguez C, Fernandez-Delgado R, Usera F, Enjuanes L (2014) Coronavirus virulence genes with main focus on SARS-CoV envelope gene. Virus Research 194:124-37. doi: 10.1016/j.virusres.2014.07.024.

Dhama K, Sachan S, Khandia R, Munjal A, Iqbal HMN, Latheef SK, Karthik K, Samad HA, Tiwari R, Dadar M (2016) Medicinal and Beneficial Health Applications of Tinospora cordifolia (Guduchi): A Miraculous Herb Countering Various Diseases/Disorders and its Immunomodulatory Effects. Recent Patents on Endocrine, Metabolic and Immune Drug Discovery 10(2):96-111.

Dhama K, Karthik K, Khandia R, Munjal A, Tiwari R, Rana R, Khurana SK, Sana Ullah, Khan RU, Alagawany M, Farag MR, Dadar M, Joshi SK (2018) Medicinal and therapeutic potential of herbs and plant metabolites / extracts countering viral pathogens - Current knowledge and future prospects. Current Drug Metabolism 19(3):236263. 2018 Jan 29. doi: 10.2174/1389200219666180129145252.

Dhama K, Saminathan M, Jacob SS, Singh M, Karthik K, Amarpal, Tiwari R, Sunkara LT, Malik YS, Singh RK (2015) Effect of immunomodulation and immunomodulatory agents on health with some bioactive principles, modes of action and potent biomedical applications. International Journal of Pharmacology 11(4): 253-290.

Dhama K, Khan S, Tiwari R, Sircar S, Bhat S, Malik YS, Singh KP, Chaicumpa W, Bonilla-Aldana DK, Rodriguez-Morales AJ (2020a) Coronavirus Disease 2019-COVID-19. Clinical Microbiology Reviews 33(4):e00028-20.

Dhama K, Patel SK, Pathak M, Yatoo MI, Tiwari R, Malik YS, Singh R, Sah R, Rabaan AA, Bonilla-Aldana DK, RodriguezMorales AJ (2020b) An update on SARS-CoV-2/COVID-19 with particular reference to its clinical pathology, pathogenesis, immunopathology and mitigation strategies. Travel Medicine and Infectious Diseases 37: 101755. doi: 10.1016/j.tmaid.2020.101755.

Dharmendra M, Deepak S (2020) Evaluation of traditional ayurvedic preparation for prevention and management of the novel coronavirus (SARS-CoV-2) using molecular docking approach ChemRxiv, https://doi.org/10.26434/chemrxiv.12110214.v1.

Donma MM, Donma O (2020) The effects of allium sativum on immunity within the scope of COVID-19 infection. Medical Hypotheses 144:109934. doi: 10.1016/j.mehy.2020.109934.

Emirik M (2020) Potential therapeutic effect of turmeric contents against SARS-CoV-2 compared with experimental COVID-19 therapies: in silico study. Journal of Biomolecular Structure and Dynamics. 1-14. doi: 10.1080/07391102.2020.1835719.
Ferreira VH, Nazli A, Dizzell SE, Mueller K, Kaushic C (2015) The anti-inflammatory activity of curcumin protects the genital mucosal epithelial barrier from disruption and blocks replication of HIV-1 and HSV-2. PLoS ONE. https://doi.org/10.1371/journal.pone.0124903.

Gautam S, Gautam A, Chhetri S, Bhattarai U (2020) Immunity against COVID-19: Potential role of Ayush Kwath. Journal of Ayurveda and Integrative Medicine. https://doi.org/10.1016/j.jaim.2020.08.003.

Gilling DH, Kitajima M, Torrey JR, Bright KR (2014) Antiviral efficacy and mechanisms of action of oregano essential oil and its primary component carvacrol against murine norovirus. Journal of Applied Microbiology 116(5):1149-63. doi: 10.1111/jam.12453.

Goyal P K, Sharma P, Parmar J, Verma P (2011) Radiation-induced testicular injury and its amelioration by Tinospora cordifolia (an Indian medicinal plant) extract. Evidence-Based Complementary and Alternative Medicine. https://doi.org/10.1155/2011/643847.

Gupta H, Gupta M, Bhargava S (2020) Potential use of Turmeric in COVID-19. Clinical and Experimental Dermatology https://doi.org/10.1111/ced.14357.

Gruhlke MC, Nicco C, Batteux F, Slusarenko AJ (2016) The Effects of Allicin, a Reactive Sulfur Species from Garlic, on a Selection of Mammalian Cell Lines. Antioxidants (Basel) 6(1):1. doi: 10.3390/antiox6010001.

Hemalatha R, Babu KN, Karthik M, Ramesh R, Kumar BD, Kumar PU (2011) Immunomodulatory activity and Th1/Th2 cytokine response of Ocimum sanctum in myelosuppressed swiss albino mice. Trends in Medical Research 6:23-31.

Hoang BX, Shaw DG, Fang W, Han B (2020) A Possible Application of High Dose Vitamin $\mathrm{C}$ in the Prevention and Therapy for Coronavirus Infections. Journal of Global Antimicrobial Resistance: S2213-7165(20)30258-7. doi: 10.1016/j.jgar.2020.09.025.

Kapoor L (1990) handbook of ayurvedic medicinal plants (L. Kapoor (Ed.)). CRC Press. https://trove.nla.gov.au/work/\%0A16589020?q\&versionId=19467951.

Kim WY, Kim JM, Han SB, Lee SK, Kim ND, Park MK, Kim CK, Park JH (2000) Steaming of ginseng at high temperature enhances biological activity. Journal of Natural Products 63: 1702-1704.

Kim SK, Park JH (2011) Trends in ginseng research in 2010. Journal of Ginseng Research 35, 389-398.

Kim SO, Kundu JK, Shin YK, et al.(2006) Gingerol inhibits COX2 expression by blocking the activation of p38 MAP kinase and NF-kappaB in phorbol ester-stimulated mouse skin. American Society for Nutrition Journal of Nutrition 136:1150-1155. 
Krupanidhi S, Abraham Peele K, Venkateswarulu TC, Ayyagari VS, Nazneen Bobby M, John Babu D, Venkata Narayana A, Aishwarya G (2020) Screening of phytochemical compounds of Tinospora cordifolia for their inhibitory activity on SARS-CoV2: an in silico study. Journal of Biomolecular Structure and Dynamics 1-5. doi: 10.1080/07391102.2020.1787226.

Lee JS, Ko EJ, Hwang HS, Lee YN, Kwon YM, Kim MC, Kang SM ( 2014a) Antiviral activity of ginseng extract against respiratory syncytial virus infection. International Journal of Molecular Medicine 34:183-190.

Lee JS, Hwang HS, Ko EJ, Lee YN, Kwon YM, Kim MC, Kang SM ( 2014b) Immunomodulatory activity of red ginseng against influenza A virus infection. Nutrients 6: 517-529.

Lee JS, Lee YN, Lee YT, Hwang HS, Kim KH, Ko EJ, Kim MC, Kang SM (2015) Ginseng protects against respiratory syncytial virus by modulating multiple immune cells and inhibiting viral replication. Nutrients 7:1021-1036.

Li X, Fang Q, Tian X, Wang X, Ao Q, Hou W, Bai S (2017) Curcumin attenuates the development of thoracic aortic aneurysm by inhibiting VEGF expression and inflammation. Molecular Medicine Reports 16(4): 4455-4462. https://doi.org/10.3892/mmr.2017.7169.

Lo AH, Liang YC, Lin-Shiau SY, Ho CT, Lin JK (2002) Carnosol, an antioxidant in rosemary, suppresses inducible nitric oxide synthase through downregulating nuclear factor-kappaB in mouse macrophages. Carcinogenesis 23:983-91.

Maggini S, Wintergerst ES, Beveridge S, Hornig DH (2007) Selected vitamins and trace elements support immune function by strengthening epithelial barriers and cellular and humoral immune responses. British Journal of Nutrition https://doi.org/10.1017/S0007114507832971.

Mahima, Verma AK, Tiwari R, Karthik K, Chakraborty S, Deb R, Dhama K (2013) Nutraceuticals from fruits and vegetables at a glance: a review. Journal of Biological Sciences 13(2): 38-47.

Malik YS, Sircar S, Bhat S, Sharun K, Dhama K, Dadar M, Tiwari R, Chaicumpa W (2020) Emerging novel coronavirus (2019$\mathrm{nCoV}$ )-current scenario, evolutionary perspective based on genome analysis and recent developments. Veterinary Quarterly 40(1):68-76. doi: 10.1080/01652176.2020.1727993.

Mohan L, Amberkar MV, Kumari M (2011) Ocimum sanctum Linn. (TULSI) - an overview. International Journal of Pharmaceutical Sciences Review and Research 7:51-53.

Mondal S (2010) Antimicrobial and immunomodulatory effects of Tulsi (Oscimum snctum Linn.). Available from: http://ayushportal.nic.in/EMR/CLINICAL_FINAL_REPORT-4.pdf.
Mondal S, Varma S, Bamola VD, et al. (2011) Double-blinded randomized controlled trial for immunomodulatory effects of Tulsi (Ocimum sanctum Linn.) leaf extract on healthy volunteers. Journal of Ethnopharmacology 136(3):452-456. doi:10.1016/j.jep.2011.05.012.

Munoz FM (2015) Respiratory syncytial virus in infants: is maternal vaccination a realist ic strategy?. Current Opinion in Infectious Diseases 28:222-224.

Nahak G, Sahu RK (2011) Phytochemical evaluation and antioxidant activity of Piper cubeba and Piper nigrum. Journal of Applied Pharmaceutical Science 1:153-7.

Najmanová I, Vopršalová M, Saso L, Mladěnka P (2019). The pharmacokinetics of flavanones. Critical Reviews in Food Science and Nutrition 60(18): 1-17. DOI: https://doi.org/10.1080/10408398.2019.1679085.

Neumann G, Noda T, Kawaoka Y (2009) Emergence and pandemic potential of swine-origin H1N1 influenza virus. Nature 459 : 931-939.

Niphade SR, Asad M, Chandrakala GK, Toppo E, Deshmukh P (2009) Immunomodulatory activity of Cinnamomum zeylanicum Bark. Pharmaceutical Biology 47:1168-1173.

Panchabhai TS, Kulkarni UP, Rege NN (2008). Validation of therapeutic claims of Tinospora cordifolia: A review. Phytotherapy Research 22(4), 425-441. https://doi.org/10.1002/ptr.2347.

Panda VS, Suresh RN(2009) Evaluation of cardioprotective activity of Ginkgo biloba and Ocimum sanctum in rodents. Alternative Medicine Review 14:161-71.

Panyod S, Ho CT, Sheen LY (2020) Dietary therapy and herbal medicine for COVID-19 prevention: A review and perspective. Journal of Traditional and Complementary Medicine 10(4):420-427.

Pattanayak P, Behera P, Das D, Panda S (2010) Ocimum sanctum Linn. A reservoir plant for therapeutic applications: an overview. Pharmacognosy reviews 4:95e105. https://doi.org/10.4103/09737847.65323.

Peterson CT, Rodionov DA, Iablokov SN, Pung MA, Chopra D, Mills PJ, et al. (2019) Prebiotic potential of culinary spices used to support digestion and bioabsorption. Evidence-Based Complementary and Alternative Medicine 8973704. https://doi.org/10.1155/2019/8973704.

Pilau MR, Alves SH, Weiblen R, Arenhart S, Cueto A P, Lovato LT (2011) Antiviral activity of the Lippia graveolens (Mexican oregano) essential oil and its main compound carvacrol against human and animal viruses. Brazilian Journal of Microbiology https://doi.org/10.1590/S1517-83822011000400049. 
Prasanth DSNBK, Murahari M, Chandramohan V, Panda SP, Atmakuri LR, Guntupalli C (2020) In silico identification of potential inhibitors from Cinnamon against main protease and spike glycoprotein of SARS CoV-2. Journal of Biomolecular Structure and Dynamics 1-15. doi: 10.1080/07391102.2020.1779129.

Rabaan AA, Al-Ahmed SH, Sah R, Tiwari R, Yatoo MI, Patel SK, Pathak M, Malik YS, Dhama K, Singh KP, Bonilla-Aldana DK, Haque S, Martinez-Pulgarin DF, Rodriguez-Morales AJ, Leblebicioglu H (2020) SARS-CoV-2/COVID-19 and advances in developing potential therapeutics and vaccines to counter this emerging pandemic. Annals of Clinical Microbiology and Antimicrobials 19(1):40. doi: 10.1186/s12941-020-00384-w.

Rahal A, Mahima, Verma AK, Kumar A, Tiwari R, Kapoor S, Chakraborty S, Dhama K (2014) Phytonutrients and nutraceuticals in vegetables and their multi-dimensional medicinal and health benefits for humans and their companion animals: A review. Journal of Biological Science 14(1): 1-19.

Reinhart KM, Talati R, White CM, Coleman CI (2009) The impact of garlic on lipid parameters: a systematic review and metaanalysis. Nutrition Research Reviews. 22(1):39-48. doi: 10.1017/s0954422409350003.

Rodriguez-Morales AJ, Bonilla-Aldana DK, Tiwari R, Sah R, Rabaan AA, Dhama K (2020) COVID-19, an emerging coronavirus infection: current scenario and recent developments an overview. Journal of Pure and Applied Microbiology 14(1): 05-12. https://doi.org/10.22207/JPAM.14.1.02.

Safa O, Hassaniazad M, Farashahinejad M, Davoodian P, Dadvand H, Hassanipour S, Fathalipour M (2020) Effects of Ginger on clinical manifestations and paraclinical features of patients with Severe Acute Respiratory Syndrome due to COVID-19: A structured summary of a study protocol for a randomized controlled trial. Trials 21(1):841. doi: 10.1186/s13063-020-04765-6.

Salman H, Bergman M, Bessler H, Punsky I, Djaldetti M (1999) Effect of a garlic derivative (alliin) on peripheral blood cell immune responses. International Journal of Immunopharmacology 21(9):589-597. doi: 10.1016/s0192-0561(99)00038.

Sawai T, Itoh Y, Ozaki H, Isoda N, Okamoto K, Kashima Y, Kawaoka Y, Takeuchi Y, Kida H, Ogasawara K (2008) Induction of cytotoxic T-lymphocyte and antibody responses against highly pathogenic avian influenza virus infection in mice by inoculation of apathogenic H5N1 influenza virus particles inactivated with formalin. Immunology 124(2):155-65.

Sharma L (2017) Indian Spices: Hidden Treasure to manage Ailments. EPRA International Journal of Multidisciplinary Research 3(3) : 226-230.
Sharma U, Bala M, Kumar N, Singh B, Munshi R K, Bhalerao S (2012) Immunomodulatory active compounds from Tinospora cordifolia. Journal of Ethnopharmacology. https://doi.org/10.1016/j.jep.2012.03.027.

Shree P, Mishra P, Selvaraj C, Singh SK, Chaube R, Garg N, Tripathi YB (2020) Targeting COVID-19 (SARS-CoV-2) main protease through active phytochemicals of ayurvedic medicinal plants - Withania somnifera (Ashwagandha), Tinospora cordifolia (Giloy) and Ocimum sanctum (Tulsi) - a molecular docking study. Journal of Biomolecular Structure and Dynamics 114. doi: 10.1080/07391102.2020.1810778.

Singh B (2020) Phenolic composition, antioxidant potential and health benefits of citrus peel. Food Research International 132(109114)

Singh N, Bhalla M, Jager DP, Gilca M (2011) An Overview on Ashwagandha : A Rasayana (Rejuvenator) of Ayurveda. African Journal of Traditional, Complementary and Alternative Medicines 8(5 Suppl): 208-213.

Singh RH, Narsimhamurthy K, Singh G (2008) Neuronutrient impact of Ayurvedic Rasayana therapy in brain aging. Biogerontology 9: 369-374.

Sinha SK, Prasad SK, Islam MA, Chaudhary SK, Singh S, Shakya A (2020) Potential Leads from Liquorice against SARS-CoV-2 Main Protease using Molecular Docking Simulation Studies. Comb Chem High Throughput Screen doi: 10.2174/1386207323999200817103148.

Srivastava AK, Singh VK (2017) Biological action of Piper nigrum e the king of spices. European Journal of Cell Biology https://doi.org/10.5281/zenodo.839039.

Suanarunsawat T, Ayutthaya WDN, Songsak T, Thirawarapan S, Poungshompoo S (2011) Lipid-lowering and antioxidative activities of aqueous extracts of Ocimum sanctum L. leaves in rats fed with a high-cholesterol diet. Oxidative Medicine and Cellular Longevity 962025.

Sun X, Liu Y, Li C, Wang X, Zhu R, Liu C, Li Y (2017) Recent advances of curcumin in the prevention and treatment of renal fibrosis. BioMed Research International 2418671. https://doi.org/10.1155/2017/2418671.

Tian S, Hu W, Niu L, Liu H, Xu H, Xiao SY (2020) Pulmonary pathology of early-phase 2019 novel coronavirus (COVID-19) pneumonia in two patients with lung cancer. Journal of Thoracic Oncology 15: 700-704. https://doi.org/10.1016/j.jtho.2020.02.010.

Tiwari R, Chakraborty S, Saminathan M, Dhama K, Singh SV (2014) Ashwagandha (Withania somnifera): Role in safeguarding 
health, immunomodulatory effects, combating infections and therapeutic applications: A review. Journal of Biological Sciences 14(2): 77-94.

Tiwari R, Latheef SK, Ahmed I, Iqbal HMN, Bule MH, Dhama K, Samad HA, Karthik K, Alagawany M, El-Hack MEA, Yatoo MI, Farag MR (2018) Herbal Immunomodulators - A Remedial Panacea for Designing and Developing Effective Drugs and Medicines: Current Scenario and Future Prospects. Current Drug Metabolism 19(3):264-301. doi: $10.2174 / 1389200219666180129125436$.

Tiwari R, Dhama K, Sharun K, Iqbal Yatoo M, Malik YS, Singh R, Michalak I, Sah R, Bonilla-Aldana DK, Rodriguez-Morales AJ (2020) COVID-19: animals, veterinary and zoonotic links. Veterinary Quarterly 40(1):169-182. doi: $10.1080 / 01652176.2020 .1766725$.

Tripathi MK, Singh P, Sharma S, Singh TP, Ethayathulla AS, Kaur $P$ (2020) Identification of bioactive molecule from Withania somnifera (Ashwagandha) as SARS-CoV-2 main protease inhibitor. Journal of Biomolecular Structure and Dynamics 1-14. doi:10.1080/07391102.2020.1790425.

Tsui PF, Lin CS, Ho LJ, Lai JH (2018) Spices and atherosclerosis. Nutrients https://doi.org/10.3390/nu10111724.

Valizadeh S, Katiraee F, Mahmoudi R, Fakheri T, Mardani K (2015) Biological properties of Cinnamomum zeylanicum essential oil: phytochemical component, antioxidant and antimicrobial activities. International Journal of Food Safety, Nutrition and Public Health 6:174-184.

Ven Murthy MR, Ranjekar PK, Ramassamy C, Deshpande M (2012) Scientific Basis for the Use of Indian Ayurvedic Medicinal Plants in the Treatment of Neurodegenerative Disorders: 1. Ashwagandha. Central Nervous System Agents in Medicinal Chemistry 10(3):238-46. https://doi.org/10.2174/1871524911006030238.

Vyas VK, Bhandari P, Patidar R (2011) A comprehensive review on Withania somnifera dunal. In Journal of Natural Remedies 11(1): 1-13. https://doi.org/10.18311/jnr/2011/43.

Wang L, Yang R, Yuan B, Liu Y, Liu C ( 2015) The antiviral and antimicrobial activities of licorice, a widely-used Chinese herb. Acta Pharmaceutica Sinica B 5(4):310-15.
Webb AL, Villamor E (2007) Update: Effects of antioxidant and non-antioxidant vitamin supplementation on immune function. Nutrition Reviews 65(5):181-217. doi: 10.1111/j.17534887.2007.tb00298.x.

Xu X, Cai Y, Yu Y (2018) Effects of a novel curcumin derivative on the functions of kidney in streptozotocin-induced type 2 diabetic rats. Inflammopharmacology 26: 1257-1264. DOI: https://doi.org/10.1007/s10787-018-0449-1.

Yatoo MI, Hamid Z, Parray OR, Wani AH, Ul Haq A, Saxena A, Patel SK, Pathak M, Tiwari R, Malik YS, Sah R, Rabaan AA, Rodriguez Morales AJ, Dhama K (2020) COVID-19 - Recent advancements in identifying novel vaccine candidates and current status of upcoming SARS-CoV-2 vaccines. Human Vaccines and Immunotherapeutics 1-14. doi: 10.1080/21645515.2020.1788310.

Ye M, Wysocki J, William J, Soler MJ, Cokic I, Batlle D (2006) Glomerular localization and expression of angiotensin-converting enzyme 2 and angiotensin-converting enzyme: Implications for albuminuria in diabetes. Journal of the American Society of $\begin{array}{lllll}\text { Nephrology } & 17 & \text { (11) } 3067-3075 ; & \text { DOI: }\end{array}$ https://doi.org/10.1681/ASN.2006050423.

Zahedipour F, Hosseini SA, Sathyapalan T, et al.(2020) Potential effects of curcumin in the treatment of COVID-19 infection. Phytotherapy Research. 1-10. https://doi.org/10.1002/ptr.6738.

Zhai WJ, Zhang ZB, Xu NN, Guo YF, Qiu C, Li CY, et al.(2016) Piperine plays an anti-inflammatory role in Staphylococcus aureus endometritis by inhibiting activation of NF-kB and MAPK pathways in mice. Evidence-Based Complementary and Alternative Medicine 2016:8597208. https://doi.org/10.1155/2016/8597208.

Zhen H, Fang F, Ye DY, Shu SN, Zhou YF, Dong YS, Nie XC, Li G (2006) Experimental study on the action of allitridin against human cytomegalovirus in vitro: Inhibitory effects on immediateearly genes. Antiviral Research 72(1):68-74.

Zheng Y (2020) COVID-19 and the cardiovascular system. Nature Reviews. Cardiology 17: 259-260. https://doi.org/10.1038/s41569020-0360-5.

Zhou P, Yang X-L, Wang X-G, Hu B, Zhang L, Zhang W, et al. (2020) A pneumonia outbreak associated with a new coronavirus of probable bat origin. Nature 579:270e3. https://doi.org/10.1038/s41586-020-2012-7. 